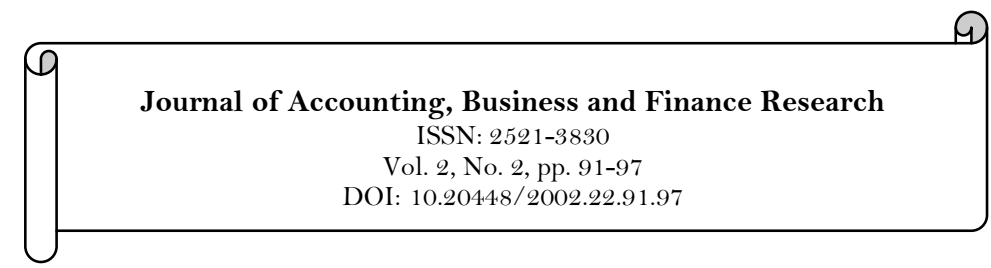

\title{
Assessment of the Development and Growth of Nigerian Economy as a Function of FDI Flows
}

\author{
Joseph Oluseye Mokuolu ${ }^{1}$ \\ ${ }^{1}$ Department of Banking and Finance, Ekiti State University, Ado-Ekiti, Nigeria. \\ Email:joseph.mokuolu@eksu.edu.ng
}

\begin{abstract}
An attempt is made to postulate a model based on the assumption that the inflow of Foreign Direct Investment (FDI) affect the growth of Nigerian economy. A simple econometric modeling approach was applied to time series annual Nigerian data for a period covering forty eight years. The result revealed that there exist a strong positive relationship between FDI flows and economic growth represented by the Gross Domestic Product (GDP). The implication of this is that the inflows of FDI reasonably affect the level of growth of the economy with the level of correlation and the positive sign between the two variables. The study concluded that FDI is germane to the economic development of a developing country and on the basis of the findings it is recommended that a positive step should be taken to encourage indigenous companies to understudy and learn the process and strategies of the MNCs.
\end{abstract}

\author{
Keywords: \\ FDI \\ GDP \\ Economic growth \\ Economic development. \\ JEL Classification: \\ F49, O10. \\ Licensed: \\ This work is licensed under a \\ Creative Commons Attribution \\ 4.0 License. \\ Publisher: \\ Scientific Publishing Institute
}

\section{Introduction}

Economic growth and development has always remained an ultimate concern to both the government and the citizenry, the quest which has made the pursuant and attraction of Foreign Direct Investment (FDI) to a nation a paramount task. This is as a result of its perceived implication on the people and the country in taking its rightful position in the global circle. Adegbite and Ayadi (2010) in their study corroborated that FDI assist in filling the domestic revenue generation gap in a developing economy and thereby been able to generate sufficient fund to meet their expenditure needs. To this extent the government and the people often strive to employ the right policy that will not only ensure stability but also enhances the growth of the economy. To achieve improved living condition the nation must work very hard to generate sufficient income to ameliorate the per capital income of its citizenry and as well as set apart some of the income for future use. This objective can only be achieved through investment and given the low level of capital formation in less developed countries thus one of the ways of doing this is to rely primarily on foreign direct investment as a source of external finance to stimulate their economy.

However, the process of globalization marked by a rapid increase in the internationalization of production is a subject of intense interest to scholars in several academic fields. While most economists view the issue of foreign capital as a blessing for LDC, many sociologists and political scientist consider it as a curse seeing it as a manifestation of an exploitative capitalist world system (Amin, 1990; Bornschier \& Christopher, 1985; Frank, 1969; Wallerstein, 1974).

It is an ongoing debate that FDI is superior to other types of capital inflows in stimulating economic growth of a nation for several reasons. FDI is expected to be less volatile and offer not just capital but an avenue to get involved in modern technology and know how. This view is strongly supported and embraced by every regime in Nigeria government which has been pursuing policies to attract FDI in other to initiate economic recovery after a prolonged period of recession and micro economic instability. However as laudable as this move is, empirical evidence supporting this policy advice is surprisingly hard to come by Nunnenkamp and Julius (2004).

The debate between Firebaugh (1996) and Dixon and Boswell (1996) on the influence of foreign investment on economic growth tend to heat up this topic. It is in the light of this imbroglio that this work seeks to know the relationship between Foreign Investment and the economy of Nigeria. Specifically the work attempt to examine the direction of relationship and the effect FDI has on the economic growth and development of Nigeria. 


\section{Review of Literature}

In the bid to attract foreign direct investment, countries especially the developing countries employ different policy measures to boost their economies through FDI attraction with the thinking that export of capital by the Multinational Corporation (MNC's) promotes economic growth by creating industries, transferring technology and fostering a modern perspective in the local population. Others are of the opinion that foreign investment is expected to increase the rate of investment from domestic sources as a result of spillover effect.

This work therefore intends to affirm which of the argument is true in Nigeria case to justify government policy on embarking on FDI drive.

\subsection{Review of Empirical Studies}

A large number of empirical studies on the role of FDI in host countries suggest that FDI is an important source of capital which complements domestic private investment and is usually associated with new job opportunities, enhancement of technology transfer and boosts overall economic growth in host countries.

De Mello Jr (1997) attempted to find support for an FDI-led growth hypothesis when time series analysis and panel data estimation for a sample of 32 OECD and non- OECD countries covering the period 1970-1990 were made. He estimates the impact of FDI on capital accumulation and output growth in the recipient economy. Whereas, Nair-Reichert and Weinhold (2001) in the work apply mixed fixed and random estimation to examine the relationship between FDI and growth in developing countries and discovered that there is a causal link between FDI and growth. When Ericsson and Irandoust (2001) examined the causal effects between FDI growth and output growth for the four OECD countries applying a multi-country framework to data from Denmark, Finland, Norway and Sweden they could not detect any causal relationship between FDI and output growth. They then suggested that the specific dynamics and nature of FDI entering these countries could be responsible for these no-causality results.

Liu, Siler, Wang, and Wei (2000) tested the existence of a long-run relationship among economic growth, foreign direct investment and trade in China. Using a cointegration framework with quarterly data for exports, imports, FDI and growth from 1981 to 1997, the research found the existence of a bi directional causal relationship among FDI, growth, and exports.

Chakrabortys and Basu (2002) utilize the technique of cointegration and error- correction modeling to examine the link between FDI and economic growth in India. The results suggest that GDP in India is not Granger caused by FDI, and the causality runs more from GDP to FDI.

Chowdhury and Mavrotas (2005) examined the causal relationship between FDI and economic growth for three developing countries, namely Chile, Malaysia and Thailand. They found that it is GDP that causes FDI in the case of Chile and not vice versa, while for both Malaysia and Thailand, there is a strong evidence of a bi-directional causality between the two variables. Choe (2003) detects two-way causation between FDI and growth, but the effects are more apparent from growth to FDI.

Duasa (2007) examined the causality between FDI and output growth in Malaysia, the study found no strong evidence of causal relationship between FDI and economic growth. This indicates that, in the case of Malaysia FDI does not cause economic growth, vice versa, but FDI does contribute to stability of growth as growth contributes to stability of FDI.

The results from these bilateral causality tests are mixed. This again indicates that the relationship between FDI and economic growth is far from straightforward. It varies across countries and time periods. In addition, there are some drawbacks to the causality tests reviewed above. Most of these studies employ Granger causality tests in the framework.

The economic effects of foreign capital have been linked theoretically and empirically to the availability of human capital in host countries. Bornschier and Christopher (1985) find in their study of 69 developing countries, 1970-1989, that the benefits of foreign direct investment are contingent on a nation's having the capacity to absorb the embodied technologies. In their initial analysis, foreign investment flows are positively associated with economic growth, holding constant the initial level of development, educational measures, government consumption, and a proxy for market distortions; but the estimated coefficient is only marginally significant. Inclusion of an interactive term of foreign direct investment and human capital indicates that foreign investment is most beneficial for developing countries with high levels of human capital. Similarly, Blomstöms, Robert, and Mario (1994) reported that foreign capital is most productive among high income countries. These studies, however, do not address the effects of the stock of foreign investment on growth.

Finally, it has been argued that the growth effects of FDI depend on the interplay between industry and host-country characteristics. Two opposing hypotheses are advanced in the literature. Building upon a standard Heckscher-Ohlin model structure and augmenting it by international technology flows, Kojima (1973) reckons that FDI in developing countries will be more growth enhancing if it is undertaken in more labor intensive and less technology intensive industries. In these industries, the technological differences between the affiliates of foreign direct investors in developing countries and the 
local enterprises are considered relatively small. Therefore, technological spillovers to local enterprises should be more likely. By contrast, Dutt (1997) develops a Keynesian model with international transfers of capital and technology (but without local technological spillovers), from which he concludes that the impact of FDI on economic growth in developing countries should be greater if the inflow of FDI goes into technologically advanced industries. The rationale behind this proposition is that an increase in the capital stock in technologically less advanced industries lowers the export prices in developing host countries and, thus, leads to a deterioration of their terms of trade.

Kathuria (2000) takes another look at this problem by looking at an indirect measure of productivity spillovers, namely the difference in productivity level between the most efficient firm and the average firm in an industry. The study tests, for the Indian industry, the hypothesis that the presence of foreign owned firms in the industry reduces the difference in productivity level over time. Secondly, the fall in the difference is larger for the firms that invest in learning or research and development (R\&D) activities. The reasoning is that if positive spillovers exist, the difference in productivity levels between the most efficient firm and the average firm should be smaller when foreign firms are present. This is due to the fact that the presence of foreign firms increases the efficiency of domestic firms as a result of which the gap between productivity levels narrows.

Kathuria (2000) finds that the larger the sales shares of foreign firms in the sector, the more negative the spillover for the local firms will be. One possible explanation for this could be that foreign firms and domestic firms are competing in the same market, which forces local firms to operate at higher costs. Kathuria (2000) finds that the presence of foreign firms has a negative spillover impact on the difference in efficiency of local firms whereas available foreign technical capital stock results in learning by the local firms leading to reduced differences in productivity levels.

Furthermore, for the second research question Kathuria (2000) finds that spillovers are not automatic consequence of foreign firm's presence and a certain level of investment in R\&D is needed for the domestic firms to be able to use the spilled knowledge. Whether or not domestic firms are able to adopt foreign technology depends on their own R\&D decision. Blomström and Sjöholm (1998) come to a similar conclusion.

The extent of spillovers is not determined by the degree of foreign presence alone. Instead, the results are related to the firm's investment decisions. The more the MNC invests in new technology, the higher the spillovers, ceteris paribus, because they are related to the size of the technology gap. The more the local firm invests in learning, the more potential spillovers it is able to absorb.

A first attempt to discriminate empirically between the two hypotheses was undertaken by Dutt (1997). In contrast to both models, he finds no difference in the growth impact of FDI between hightechnology and low-technology industries. However, Dutt (1997) empirical analysis is flawed in three respects. First, Dutt (1997) does not distinguish between resource-seeking FDI in the primary sector and FDI in manufacturing. In addition to six manufacturing industries, his high technology group includes "coal and petroleum products". Second, Dutt (1997) industry classification ignores that, irrespective of the technology intensity, the growth impact of FDI in manufacturing should differ depending on whether FDI is efficiency-seeking or market-seeking. Third, the classification of "metals" as a high-technology industry is in conflict with the industry characteristics.

On whether FDI affect economic growth in Nigeria the empirical reports has not been unanimous, for example Keke, Olomola, and Saibu (2003) in their research work investigated the effect of Foreign Private Investment on economic growth of Nigeria between 1970-2000 using co integration and error correction mechanism to ascertain whether causality runs between economic growth and foreign capital inflows in the Nigerian economy. The result of their work revealed that causality runs in both directions from economic growth to foreign capital inflows and that foreign private investment could contribute significantly to growth of Nigeria economy. This result is in line the submission of Chete (1998) who examined the determinants of foreign direct investment in Nigeria using an error correction model he found out that in the short run, FDI is sensitive to real growth and lending rates; the inflation rate and the level of public investment an political instability. He therefore suggested the need to moderate the rate of domestic inflation through the implementation of monetary and fiscal policies and the need to ensure political stability.

In another work by Judith (2007) where she investigated whether FDI affects economic growth in Nigeria using regression analysis with data about development obtained from World Development Indicators for the period covering 1965-2004. The result of the analysis of Nigeria shows that the relationship between FDI and economic growth is negative. The implication of this is that FDI takes place in extractive industries and MNCs only invest to exploit the natural resources to export them to their home country. MNCs do not invest in relationships with local producers. So, local producers do not benefit from any spillovers.

In a recent study by Adegbite and Ayadi (2010) using annual time series data (1980-2007) to measure the linear relationship between measures of growth and that of FDI, by utilizing the Spearman's rho he found out that FDI has not significantly contributed to economic growth in Nigeria but human factor is 
an important factor in FDI-growth debate in the country. This however is adduced to the level of infrastructural development in Nigeria and if she puts sufficient investment into high levels of human capital, she can exploit the technological spillovers associated with FDI attraction.

From the foregoing all empirical works on the effect of FDI on Nigerian economy has been stream lined to reflect exploitative hypothesis of FDI in Nigeria focusing on different aspect of the economy employing either co integration, regression or granger causality test. This study however intends to validate and take a position from the ongoing debate in literature by examining the effect of FDI on Nigeria in sustaining the growth and development of the economy.

\subsection{FDI Trends and Performance in Nigeria}

Today, the FDI story of Nigeria is dominated by the oil industry. It was not always so. At independence, in 1960, there was a widespread FDI presence in the economy. Policy design thereafter narrowed the scope for FDI and decades of political instability, economic mismanagement and endemic corruption further reduced Nigeria's ability to attract and retain FDI. This was compounded by a relentless deterioration of the country's social conditions and physical infrastructure, in spite of increased public revenues generated by the oil sector.

While oil has played an important role in Nigeria, data show that over 70 per cent of the population lives on less than one dollar a day (this represents a quarter of all Africans living in this condition). The manufacturing sector, has hardly progressed and only 3 per cent of agriculture is mechanized.

The return to democracy in 1999 has created the opportunity for economic renewal and an associated broader base of FDI. To reap the benefit from FDI, the Government of Nigeria undertook ambitious measures with a view to improve the investment climate. The reform process also takes into account the potential role that could play the Diaspora (close to 5 million Nigerians live abroad). The policy changes have started bearing fruits and if sustained, they will certainly provide an environment more conducive to private investment and contribute to enhance the attractiveness to FDI of Nigeria's large and growing market.

However, in the recent time the activities of the FDIs is been threatened by the dwindling oil price in the global market and its antecedent effect on the economy thereby paving way for the withdrawal of certain interest. In addition to this is the menace of insurgence from the various terrorist groups in the country.

\subsection{FDI Size and Growth}

FDI flows to Nigeria have been profoundly affected by the development of the oil sector, its world price and the Government's policies in this area.

In 1970, one year before Nigeria joined the Organization for the Petroleum Exporting Countries (OPEC) FDI flows stood at \$205 million. By 1975 they had reached $\$ 470$ million.FDI flows also reacted positively to more attractive fiscal terms for private sector participation in oil and gas that were introduced in 1986. The reduction of the Nigerian National Petroleum Corporation (NNPC) stake in Shell Nigeria and other oil companies from 80 to 60 per cent, which took place in 1989 (mergers and acquisition (M\&A) data shows $\$ 1$ billion worth of such transactions in 1989 after which FDI inflows to Nigeria have never decreased below $\$ 1$ billion per year) also had a positive impact.

In the same way, although there are indications that non-oil FDI is rising the correlation between the level of world oil prices and the FDI inflows to Nigeria is particularly strong. This is especially the case since the early 2000s, when the rise in oil prices undoubtedly explains most of the sharp increase in FDI.

FDI inflows in sectors other than oil were directly affected by the various private sector policies adopted since 1970s. For instance FDI inflows fell in the aftermath of the Second Indigenization Decree, which pushed many TNCs to divest. Among those were Citigroup, IBM and Barclays Bank in 1979. Restrictions on the entry of non-oil FDI continued until the late 1980s. In 1989, they were partially reversed, which contributed to the shift in the levels of FDI after that year. However, it was not until 1995 that the National Investment Promotion Act opened virtually all areas of the economy to foreign investors. This was accompanied by the Foreign Exchange Decree, which eased access to foreign exchange for business purposes. More recently, the improved macroeconomic environment and the reforms to the business environment explain the increase in non-oil FDI.

Between 1970 and the mid - 1990s, Nigeria as the primary destination of FDI inflows to Africa accounted for more than 30 per cent of all FDI inflows to the continent. This is largely a result of its oil attractiveness. However, in 2007 , notwithstanding the booming oil industry, Nigeria accounted for only about 16 per cent of total FDI inflows to Africa. Its leading role in terms of attracting FDI started eroding due to the surge of FDI inflows to other oil rich countries, such as Angola and Sudan. Another factor is the improved FDI performance of other large African countries such as Egypt and South Africa, which were successful in attracting FDI in diverse sectors of their economies.

Given its population, Nigeria's recent underperformance in FDI attraction within Africa is becoming more pronounced in the first half of the 1990s, per capita FDI inflows were higher in Nigeria than in any 
other African country with the exception of Angola and Equatorial Guinea. Thereafter, other African countries began to catch up. In the most recent period (2001-2007), the average per capita FDI inflows to other large African countries and other oil producers in the continent all exceeded those to Nigeria. This indicates that Nigeria is not sharing fully the growing non-oil FDI to the continent.

Nigeria is the dominant recipient of FDI within the Economic Community of West African Countries (ECOWAS) group accounting for more than 70 per cent of the group inflows since 2001, in the 1970s, Nigeria attracted about half of the FDI inflows to the region. The increased Nigeria share since then reflect both the less restrictive conditions for oil FDI and the growing foreign interest for the sector. In terms of absolute FDI stock, Nigeria remains second only to South Africa in the continent with $\$ 63$ billion and $\$ 93$ billion respectively. In per capita terms, however, its relative underperformance is evident, and while its stock $(\$ 424)$ is at par with the African average $(\$ 405)$, it is much smaller than that of other oil-producing countries, and of South Africa and Egypt. FDI to Nigeria is nonetheless a key contributor to the country's capital accumulation. During 2001-2007 FDI accounted for more than half the gross fixed capital formation (GFCF) compared to an average of around 15 per cent in the rest of Africa, and 12 per cent for developing countries as a group.

\section{Research Methodology}

The focus of this research work is to investigate FDI and its relationship with economic growth and development of Nigerian economy. Simple econometric modeling patterned after the distributed lag model construct was adopted to co integrate the estimated model. The method was applied to time series annual Nigerian data derived from 1960 through 2008 which was transformed into natural logarithms with the hope of reducing the effect of possible econometric problems; especially serial correlation, heteroscedacity, functional forms and multicollinearity.

\subsection{Model Specification}

An attempt is made to postulate a model based on the assumption that the inflow of FDI affect the growth of Nigerian economy. Autoregressive distributed lag (ARDL) models were commonplace in energy analysis until the 1980s and the approach involves testing whether a long-run relationship exists among the variables involved in a model. The model is based on the reasoning that the growth of an economy represented by the GDP is a function of Foreign Direct Investment which have direct effect on the economic growth and development of a nation as depicted by the following econometric model:

The Equation can be rewritten to read:

$$
\mathrm{GDP}=\mathrm{f}(\mathrm{FDI}) \ldots \ldots \ldots \ldots \ldots \ldots(1)
$$

$$
\mathrm{GDP}=\mathrm{b}_{0}+\mathrm{b}_{1} \mathrm{X}_{1}+\mathrm{E} \ldots \ldots \ldots(2)
$$

Where;

GDP $=$ Gross Domestic Product

$\mathrm{FDI}=$ Foreign Direct Investment

$\mathrm{b}_{0}, \mathrm{~b}_{1}, \mathrm{~b}_{2}, \beta_{0}, \beta_{1} \ldots . . \mathrm{b}_{3}, \beta_{2}=$ Beta weights

$\mathrm{X}_{1}=$ Foreign Direct Investment

$\mathrm{E}=$ Errors

The dependent variable is the traditional determinant income which is represented by the real Gross Domestic Product measured in 1990 value.

The model written above will be regressed to know the effect of the determinant of the independent variable on the income of the nation. Income represented by the real GDP is the most commonly used determinant to measure the growth of an economy and is expected to have a positive relation with gross fixed capital formation and foreign investment in line with Keynesian investment theory.

Secondary data used for this study are sourced from various publications and the period of analysis is 1960-2008, a period covering 49 years and all data are annual and computed from the Central Bank of Nigeria (CBN) Annual reports and Statistical Bulletin.

\subsection{Variables Description}

An attempt is made to postulate a model that seeks to examine the effect of FDI on the GDP representing the economy of Nigeria. For this reason the growth rate is derived using absolute annual change in GNP to annual flow of direct investment. This variable is assumed to be exogenously determined and it describes the level or rate of activity in an economy.

\section{Data Analysis, Result Presentation and Interpretation}

The model earlier stated is estimated, analyzed and interpreted to investigate the effect of FDI and its relationship with economic growth of Nigeria using simple econometric model.

It then suffices to statistically test the formulated hypotheses using the Least Squares regression technique. In order to investigate the relationship between FDI and economic growth and development in 
Nigeria, a regression analysis was done and the autoregressive distributed lag ARDL estimates of the Akaike information criterion displayed a relatively good result.

The time series property of the data on the variables used in the model was investigated by carrying out a Phillips-Peron Unit Root test on the variable. Multicollinearity is not present and the problem of auto correlation is corrected by including a auto regressive term.

\subsection{Test of Hypotheses \\ 4.1.1. Hypothesis}

The development and growth of a nation's economy is inversely related to the FDI flows.

Table-1. Regression Result showing the Relationship between FDI and Economic Growth.

\begin{tabular}{|c|c|c|c|c|c|c|c|c|}
\hline Variables & Co-efficient & $\begin{array}{l}\text { Beta } \\
\text { Coefficient }\end{array}$ & $\begin{array}{l}\mathrm{t}- \\
\text { statistic }\end{array}$ & Prob. & $\begin{array}{l}\mathrm{F}- \\
\text { Statistics }\end{array}$ & $\mathrm{R}$ & $\mathrm{R} 2$ & Sig. \\
\hline GDP & 85347.793 & & 5.884 & .000 & \multirow[b]{2}{*}{195.418} & \multirow[b]{2}{*}{.898} & \multirow[b]{2}{*}{.806} & \multirow[b]{2}{*}{.000} \\
\hline FDI & 1.844 & .898 & 13.979 & .000 & & & & \\
\hline
\end{tabular}
$\mathrm{GDP}=\mathrm{f}(\mathrm{FDI})$.

The result above establishes that there exist a strong positive relationship between FDI flows and economic growth represented by the GDP. The Akaike minimal final prediction error was used and the fourth lag on the variable was found to be appropriate. The result from the table showed that F-Statistic indicated the significance of the coefficient of FDI in explaining economic growth and vice versa.

\subsection{Summary and Implication of Findings}

The study was aimed at investigating the relationship between Foreign Direct Investment and the growth of the economy of Nigeria. The result of the data analysis revealed that there is a strong positive relationship between Foreign Direct Investment and the economic growth. This showed that the inflows of FDI reasonably affect the level of growth of the economy with the level of correlation and the positive sign between the two variables in line with the work of Keke et al. (2003).

Certain behavior patterns are observed in the light of these results. One of such is that MNCs invest in developing countries in other to exploit certain benefits which present themselves in these economies. They occur as they want to operate in markets that appear to be more profitable than their congested home markets.

\section{Conclusion and Recommendations}

The conclusion of the study is that irrespective of how we view FDI, it is still germane to the economic development of a developing country and on the basis of the foregoing findings, the following recommendations are made.

1. A positive step should be taken to encourage indigenous companies to understudy and learn the process and strategies of the MNCs so as to maximize the benefit of technological transfer the developing countries stand to gain from the mutual bilateral agreement.

2. The government should utilized to advantage the employment and labour policies by making sure that indigenous hands are trained to occupy responsible positions. By so doing Nigerians will learn to do things by herself and competently hold the forte.

\section{References}

Adegbite, E. O., \& Ayadi, F. S. (2010). The role of FDI in economic development: A study of Nigeria. World Journal of Entrepreneurship, Management and Sustainable Development, 6(1), 133-147.

Amin, S. (1990). Maldevelopment. New York: Zed Books.

Blomstöms, M., Robert, E. L., \& Mario, Z. (1994). What explains the growth of developing countries. in: William J. Baumol, Richard R. Nelson and Edward N. Wolff (Eds.), Convergence of Productivity: Cross-National Studies and Historical Evidence (pp. 243-259). New York.

Blomström, M., \& Sjöholm, F. (1998). Technology transfer and spillovers: Does local participation with multinationals matter? National Bureau of Economic Research, Working Paper 6816.

Bornschier, V., \& Christopher, C.-D. (1985). Transnational corporations and underdevelopment. New York: Praeger.

Chakrabortys, C., \& Basu, P. (2002). Foreign direct investment and growth in India: A cointegration approach. Applied Economics, 34(9), 106 1-1073.

Chete, L. N. (1998). Determinants of foreign direct investment in Nigeria: An error correction specification. The Nigerian Journal of Economic and Social Studies, 4O(1), 1-17.

Choe, J. I. (2003). Do foreign direct investment and gross domestic investment promote economic growth? Review of Development Economics, 7(1), 44-57.

Chowdhury, A., \& Mavrotas, G. (2005). FDI and growth: A causal relationship. WIDER .Research Paper.

De Mello Jr, L. R. (1997). Foreign direct investment in developing countries and growth: A selective survey. The journal of Development Studies, 34(1), 1-34. 
Dixon, W. J., \& Boswell, T. (1996). Dependency, disarticulation, and denominator effects: Another look at foreign capital penetration. American Journal of Sociology, 102(2), 543-562.

Duasa, J. (2007). Malaysian foreign direct investment and growth: Does stability matter? Journal of Economic Cooperation Among Islamic Countries, 28(2), 83-98.

Dutt, A. K. (1997). The pattern of direct foreign investment and economic growth. World Development, 25(11), 19251936.

Ericsson, J., \& Irandoust, M. (2001). On the causality between foreign direct investment and output: A comparative study. The International Trade Journal, 15(1), 1-26.

Firebaugh, G. (1996). Does foreign capital harm poor nations? New estimates based on Dixon and Boswell's measures of capital penetration. American Journal of Sociology, 102(2), 563-575.

Frank, A. G. (1969). Capitalism and underdevelopment in Latin America. New York: Monthly Review Press.

Judith, V. (2007). Multinational corporations and economic performance of developing countries: A study of Nigeria.

Kathuria, V. (2000). Productivity spillovers from technology transfer to Indian manufacturing firms. Journal of International Development, $12(3), 343-369$.

Keke, N. A., Olomola, P. A., \& Saibu, M. O. (2003). Foreign direct investment and economic growth in Nigeria: A causality test. Journal of Economic and Social Studies, 3(1), 79-91.

Kojima, K. (1973). A macroeconomic approach to foreign direct investment. Hitotsubashi Journal of Economics, 14(1), 121.

Liu, X., Siler, P., Wang, C., \& Wei, Y. (2000). Productivity spillovers from foreign direct investment: Evidence from UK industry level panel data. Journal of International Business Studies, 31(3), 407-425.

Nair-Reichert, U., \& Weinhold, D. (2001). Causality tests for cross-country panels: A New look at FDI and economic growth in developing countries. Oxford Bulletin of Economics and Statistics, 63(2), 153-171.

Nunnenkamp, P., \& Julius, S. (2004). Foreign direct investment and economic growth in developing countries: How relevant are host-country and industry characteristics? In Kiel Institute for World Economics,Working Paper No. 1176.

Wallerstein, I. (1974). The rise and future demise of the world capitalist system: Concepts for comparative analysis. Comparative Studies in Society and History, 16(4), 387-415.

\section{Sources of Statistical Data}

Central Bank of Nigeria. (Jan. 1990-Jan 2004) .Statistical Bulletin Various Issues

Nigeria, Federal Office of Statistics. (April 2004) Nigeria Statistical Fact Sheet on Economics and Social Development 1999-2003 .

Website: www.cenbank.org accessed 22/04/2007; 30/05/2007

http://www.jstor.org accessed 20/04/2007; 18/05/2007 \& 30/05/2010 